\title{
OILCROP-SUN Model for Nitrogen Management of Diverse Sunflower (Helianthus annus L.) Hybrids Production under Agro-Climatic Conditions of Sargodha, Pakistan
}

\author{
Muhammad Irfan Ahmad1,2*, Amjed Ali', Aaqil Khan², Sikandar Ali Jamro², Alam Sher², \\ Shafeeq-ur-Rahman ${ }^{3}$, Arif Rashid ${ }^{4}$ \\ ${ }^{1}$ University College of Agriculture, University of Sargodha, Sargodha, Pakistan \\ ${ }^{2}$ School of Agronomy, Anhui Agricultural University, Hefei, China \\ ${ }^{3}$ Soil Fertility Laboratory, University of Agriculture Faisalabad, Faisalabad, Pakistan \\ ${ }^{4}$ Department of Crop Biotechnology, Anhui Agricultural University, Hefei, China \\ Email: ^irfan306@outlook.com
}

How to cite this paper: Ahmad, M.I., Ali, A., Khan, A., Jamro, S.A., Sher, A., Rahman, S. and Rashid, A. (2017) OILCROPSUN Model for Nitrogen Management of Diverse Sunflower (Helianthus annus L.) Hybrids Production under Agro-Climatic Conditions of Sargodha, Pakistan. American Journal of Plant Sciences, 8, 412-427. https://doi.org/10.4236/ajps.2017.83028

Received: January 8, 2017

Accepted: February 4, 2017

Published: February 7, 2017

Copyright $\odot 2017$ by authors and Scientific Research Publishing Inc. This work is licensed under the Creative Commons Attribution International License (CC BY 4.0).

http://creativecommons.org/licenses/by/4.0/

\begin{abstract}
Decision support system for agro-technology transfer (DSSAT), OIL CROPSUN Model was used to stimulate the phenology, growth, yield of different two sunflower hybrids. i.e. Hysun-33 and S-78 by applying different nitrogen levels. The effect of nitrogen $(\mathrm{N})$ on growth and yield components of different sunflower (Helianthus annuus L.) hybrids were evaluated under agro-climatic conditions of Sargodha, Pakistan during spring 2013. The experiment was laid out in a randomized complete block design with split plot arrangement having three replications, keeping cultivars in the main plots and nitrogen levels $(0$, $45,90,135$ and $180 \mathrm{~kg} / \mathrm{ha}$ ) in sub plots. OIL CROP-SUN Model showed that the model was able to simulate the growth and yield of sunflower with an average of 10.44 error\% between observed and simulate achene yield (AY). The result of simulation indicates that nitrogen rate of $180 \mathrm{~kg} / \mathrm{ha}$ produced highest achene yield in S-78 hybrid as compared to other treatments and Hysun-33 cultivar.
\end{abstract}

\section{Keywords}

Decision Support System for Agro-Technology Transfer, Sunflower, Nitrogen, Achene Yield, Crop Modeling

\section{Introduction}

Among the crops, oil crops are playing an important role as one of the largest 
sources of energy. These are being cultivated mainly due to the use of food and non-food oils. Pakistan is facing a serious shortage of edible oil because the domestic production is not sufficient to meet our total demand. Thus country is constrained to import edible oil in large quantities involving huge expenditure in foreign exchange. A developing country like Pakistan cannot afford such a huge amount indeed. So it is imperative to enhance the domestic production to meet the increasing demand of edible oils. The area under of sunflower crop in 201213 was 700 thousand acres with seed and oil production of 378 and 144 thousand tons, respectively [1]. The sunflower is a warm season and drought tolerant crop; adapt to high temperature and moisture limited conditions. In Pakistan, sunflower grown in both rain fed and irrigated area because it is a drought resistant and deep rooted crop and pulls out water from below the root zone of soil. It showed positive response on limitation of precipitation, soil water and irrigation to growth and yield [2]. It is considered a short duration crop and grown two times in a year spring and autumn easy to adopt and produced a good yield in both season. The numbers of days are required from sowing to physical maturity 90 - 120 days. In Pakistan cultivation of exotic sunflower hybrids are not good for better yield because these are not well adapted to our agro climatic conditions. Therefore, introductions of such hybrids which are early maturating, having high oil contents and producing high seed yield under summer temperature and drought conditions [3]. The sunflower is considered potential sources of high quality edible oil in all over the world after soybean. In our country, total cultivation area is limited because production is low due to lack of proper management practices and production technologies [4]. Because farmers are not known about good cultivars, proper nitrogen requirement, plant spacing and irrigation in order to produced high seed and oil yield per hector Pakistan is depended on cultivation of exotic sunflower hybrids, the newly local developed hybrids did not receive much attention due to lack of seed sector [5]. There are various factors are responsible for obtaining the higher yield for sunflower. many studies have been done to check the effect of nitrogen on sunflower crop in different parts of the world are concluded that nitrogen is positive effect on growth, development and higher achene yield [6]-[14]. Modeling is very important tool to manage the crops in poor soil and different environmental conditions. The simulation models are helpful to give solution and increase research efficacy and improved research direction through direct feedback [15]. Crop modeling is modern tool to predict the crop performance under changing environmental conditions [16]. (DSSAT) model is very good tool to observed crop growth and yield parameters with minimum error of $11 \%$ in the predicted grain parameters. OILCROP-SUN model is a good tool in fertilizer and other input management for obtaining good yield under irrigated and semiarid environment conditions in Punjab [17]. The temperature and radiation are most important factors that are greatly affecting on our crop. Therefore crop simulation models are very helpful to give better decision in each variety and each region [18]. 


\section{Materials and Methods}

\subsection{Experimental Site and Soil}

The experiment was carried out at the Agronomic Research Area of, University of Sargodha $\left(32^{\circ} 05^{\prime \prime N}, 72^{\circ} 67^{\prime \prime E}\right)$, Pakistan during the spring seasons of 2013. The soil is sandy clay loamy somewhat poorly drained with $\mathrm{pH}$ ranging from 7.9 7.33. The nitrogen level was 0.066 to 0.052 are shown in Table 1 .

\subsection{Design and Treatments}

Prior to planting. Seed bed preparation was prepared with chisel plough and 3 cultivation with the help of common cultivar. After the preparation of field make a ridges with help of plough. The experiment was set in a Split plot arrangement under RCBD having 3 replications. The crop sowing was done by dibbler method using seed rate of $5 \mathrm{~kg} / \mathrm{ha}$. The net plot size was $4.2 \mathrm{~m} \times 6 \mathrm{~m}$ having row to row spacing $70 \mathrm{~cm}$ and plant to plant distance $20 \mathrm{~cm}$. The treatments were included with two different type of Sunflower hybrids (Hysun-33, S-278) were kept in a main plots and five levels of chemical nitrogen fertilizer (urea) consisting of $(0,45,90,135$ and $180 \mathrm{~kg} / \mathrm{ha})$ in sub plots. The sources of fertilizer are Nitrogen, Phosphorus and potassium were used in the form of urea, DAP and Potassium (k2so4).The Phosphorus and potash at the rate of $80-40 \mathrm{~kg} / \mathrm{ha}$ with $1 / 3$ of nitrogen were applied at the time of sowing in all the plots by broadcast method. Remaining $2 / 3$ dozes of urea fertilizer was used in two splits, at first irrigation and flowering stage. All other agronomic practices such as hoeing, weeding, irrigation and plant protection measure were kept normal for whole the experiment.

\subsection{Plant Sampling and Measurements}

Phonological events as well as growth and canopy development were noted at vegetative and reproductive phases of sunflower crop. The randomly 5 plants were selected by visual observations from each treated plots and tagged them for determine the number of days are need from anthesis to gained physical maturity. The first growth sampling was done after the fifteen days of sowing. Then each sample was taken every 10 days interval. The every fifteen days of interval

Table 1. Physico-chemical soil analysis of crop area.

\begin{tabular}{ccccc}
\hline \multirow{2}{*}{ Characteristic } & \multicolumn{4}{c}{ Soil sample depth } \\
\cline { 2 - 4 } & $10 \mathrm{~cm}$ & $15 \mathrm{~cm}$ & $20 \mathrm{~cm}$ & Mean \\
\hline Soil pH & 7.9 & 7.9 & 8.0 & 7.33 \\
Organic Matter (\%) & 1.32 & 1.32 & 1.04 & 1.22 \\
Total Nitrogen (\%) & 0.066 & 0.066 & 0.052 & 7.43 \\
Available P (mg.kg-1) & 4.6 & 7.5 & 10.2 & 165.33 \\
Available K (mg.kg-1 & 188 & 164 & 144 & \\
Texture & Sandy loam & Sandy loam & Sandy loam & \\
\hline
\end{tabular}


Table 2. Mean monthly weather data for sunflower growing season March-June in 2013.

\begin{tabular}{cccc}
\hline Month & Mean Temperature $\left({ }^{\circ} \mathrm{C}\right)$ & Total Rainfall $(\mathrm{mm})$ & Mean Relative Humidity (\%) \\
\hline March & 21 & 7.95 & 61.53 \\
April & 25.7 & 31 & 51 \\
May & 32.20 & 4.50 & 37.79 \\
Jun & 34.70 & 6.61 & 43.28 \\
\hline
\end{tabular}

take $10 \mathrm{~g}$ sample of leaves from each treatments by using area meter (JVC Model TK-S310EG) for the measurement of leaf area and dry weights were recorded at each harvesting stage are explained by [13]. When crop reached maturity, back of head has turned from green to yellow and color of brackets changed to brown.The harvesting was done by mechanically, ten plants were taken from each treated plots for determine number of achene ${ }^{-2}$, achene yield and total dry matter. All weather data was collected nearest meteorological around the experimental site. Weather station provided daily maximum and minimum air temperature $\left({ }^{\circ} \mathrm{C}\right)$ i.e. mean temperature, total rainfall $(\mathrm{mm})$ and mean relative humidity are shown in Table 2.

\subsection{Calibration and Evaluation of OILCROP-SUN Model}

Calibration is a process of adjusting some model parameters to the local conditions. It is also necessary for genetic coefficients for new cultivars used in modeling study. The data obtained from experiments conducted during the years, 2013 was used as input file for calibration and evaluation of the crop-model under optimum growth conditions. The comparison of model simulated outcome with observed data assesses accuracy of the model [19]. Meteorological data of the location, soil as well as plant characteristics and crop management practices data was obtained from each site and used as input data for the model [20], Genetic coefficients of hybrids sown was calculated by decision support system for agro-technology transfer (DSSAT V 4.5), by using observed data of year 2013 [21]. The experimental files that were used as inputs files includes, weather data file for the experimental period (Weather Man), soil data of respective experiment (SBuild), crop management data file (XBuild) and crop cultivar coefficients file [22]. As a part of calibration and evaluation process the simulated data for different phonological developmental stages (anthesis and maturity date).

\subsection{Statistical Indices}

Simulation performance was evaluated by calculating different statistic indices like root mean square error (RMSE), mean percentage difference (MPD), error\% and index of agreement [23] with the help of following equations:

$$
\begin{gathered}
\text { RMSE }=\left[\sum_{i=1}^{n}\left(p_{i}-o_{i}\right)^{2} / n\right]^{0.5} \\
M P D=\left[\sum_{i=1}^{n}\left(\frac{\left|o_{i}-p_{i}\right|}{o_{i}}\right) \times 100\right] / n
\end{gathered}
$$




$$
\begin{gathered}
\operatorname{Error}(\%)=\left(\frac{(p-o)}{o}\right) \times 100 \\
d=1-\left[\frac{\sum_{i=1}^{n}\left(p_{i}-o_{i}\right)^{2}}{\sum_{i=1}^{n}\left(\left|p_{i}^{\prime}\right|-\left|o_{i}^{\prime}\right|\right)^{2}}\right]
\end{gathered}
$$

The $p_{i}$ and $o_{i}$ are demonstrated as predicted and observed values respectively, $\mathrm{O}$ is the observed mean value. The Index of Agreement (d) as presented by [24] that if the d-statistic value is closer to one, then there is good agreement between the two variables that are being compared and vice versa.

\section{Result and Discussion}

\subsection{Model Calibration}

The OILCROP-SUN model was calibrated with experimental data collected during 2010 sunflower crop season. The cultivar coefficients of Hysun-33 and S-278 were estimated through trial and error and comparison of simulated and observed data. The final values for the two cultivar coefficients that determine vegetative and reproductive growth and development are presented in Table 3.

\subsection{Anthesis Date}

A close agreement was noted between observed and simulated values for sunflower phenology. The model predicted the dates for days to anthesis with a difference of one and 2 days between observed and simulated dates for Hysun-33 and S-278 hybrids, respectively are shown in Table 4. The OILCROP-SUN model

Table 3. Cultivar coefficients used with OILCROP SUN Model for sunflower hybrids.

\begin{tabular}{ccccccc}
\hline Genotype & $\mathrm{P}_{1}\left(\left({ }^{\circ} \mathrm{C}\right.\right.$ days $)$ & $\mathrm{P}_{2}($ days $)$ & $\mathrm{P}_{5}\left({ }^{\circ} \mathrm{C}\right.$ days $)$ & $\mathrm{G}_{2}(\mathrm{Nr})$ & $\mathrm{G}_{3}\left(\mathrm{mg} \cdot\right.$ day $\left.^{-1}\right)$ & $\mathrm{O}_{1}(\%)$ \\
\hline Hysun-33 & 320 & 3.55 & 732 & 1500 & 2.40 & 65 \\
S-78 & 260 & 0.80 & 712 & 1500 & 2.40 & 65
\end{tabular}

Table 4. Comparison of observed and simulated values of days to anthesis at different hybrids and different nitrogen rates.

\begin{tabular}{cccccc}
\hline Hybrids & Nitrogen Level $\left(\mathrm{kg}^{2} \cdot \mathrm{ha}^{-1}\right)$ & Observed & Predicted & ${ }^{\text {aP-O }}$ & PD (\%) \\
\hline \multirow{4}{*}{ Hysun-33 } & $0 \mathrm{~kg} \cdot \mathrm{ha}^{-1}$ & 67 & 73 & 4 & 3.4 \\
& $45 \mathrm{~kg} \cdot \mathrm{ha}^{-1}$ & 68 & 73 & 2 & 1.7 \\
& $90 \mathrm{~kg} \cdot \mathrm{ha}^{-1}$ & 69 & 73 & 1 & .8 \\
& $135 \mathrm{~kg} \cdot \mathrm{ha}^{-1}$ & 70 & 73 & -1 & -.8 \\
& $180 \mathrm{~kg} \cdot \mathrm{ha}^{-1}$ & 72 & 73 & -2 & -1.6 \\
& $0 \mathrm{~kg} \cdot \mathrm{ha}^{-1}$ & 58 & 73 & 5 & 5 \\
S-78 & $45 \mathrm{~kg} \cdot \mathrm{ha}^{-1}$ & 58 & 57 & 5 & 5 \\
& $90 \mathrm{~kg} \cdot \mathrm{ha}^{-1}$ & 59 & 57 & 4 & 3.9 \\
& $135 \mathrm{~kg} \cdot \mathrm{ha}^{-1}$ & 60 & 57 & 2 & 1.9 \\
Mean & $180 \mathrm{~kg} \cdot \mathrm{ha}^{-1}$ & 61 & 57 & 0 & 0 \\
RMSE & & & 0.77 & 0.83 & \\
\hline
\end{tabular}

${ }^{\mathrm{a}} \mathrm{P}-\mathrm{O}=$ Predicted-Observed; RMSE $=$ Root Mean Square Error. 
was able to anthesis date well and calibration results described that value for root mean square error (RMSE) was observed (1.65), was same in both sunflower hybrid S-78 and Hysun-33.

\subsection{Physiological Maturity}

The observed and simulated values of physiological maturity are shown in Table 5. There was a good agreement between observed and simulated physiological maturity. The OILCROP-SUN model was able to simulate physiological maturity well and calibration results described that value was same in both sunflower hybrid S-78 and Hysun-33.root mean square error (RMSE) was observed (1.69).

\subsection{Number of Achene $\mathrm{m}^{-2}$}

The OILCROP-SUN model was able to simulate final number of grain per meter square total well and calibrate results described there was a small difference in total number of grain per meter square between observed $\left(5887 \mathrm{~m}^{-2}\right)$ and simulate $\left(6977 \mathrm{~m}^{-2}\right)$ values of Hysun-33 hybrid and also small difference was noted in hybrid S-78 in total number of grain per meter square between observed (6535 $\left.\mathrm{m}^{-2}\right)$ and simulate $\left(6841 \mathrm{~m}^{-2}\right)$ root mean square error (RMSE) was observed (1.60) results are shown in Table 6.

\subsection{Achene Yield (kg·ha-1)}

The observed and simulated value of achene yield is shown in Table 7. There was a good agreement between observed and simulated values for achene yield $\left(\mathrm{kg} \cdot \mathrm{ha}^{-1}\right)$. The OILCROP-SUN model was able to simulate achene yield and the calibration results described that maximum value for root mean square error (RMSE) was observed $\left(191.81 \mathrm{~kg} \cdot \mathrm{ha}^{-1}\right)$. The smallest difference between simu-

Table 5. Comparison of observed and simulated values of days to physiological maturity at different sunflower hybrids and different nitrogen rates.

\begin{tabular}{|c|c|c|c|c|c|}
\hline Hybrids & Nitrogen Level $\left(\mathrm{kg} \cdot \mathrm{ha}^{-1}\right)$ & Observed & Predicted & ${ }^{\mathrm{a}} \mathrm{P}-\mathrm{O}$ & PD (\%) \\
\hline \multirow{5}{*}{ Hysun-33 } & $0 \mathrm{~kg} \cdot \mathrm{ha}^{-1}$ & 117 & 121 & 4 & 3.4 \\
\hline & $45 \mathrm{~kg} \cdot \mathrm{ha}^{-1}$ & 119 & 121 & 2 & 1.7 \\
\hline & $90 \mathrm{~kg} \cdot \mathrm{ha}^{-1}$ & 120 & 121 & 1 & .8 \\
\hline & $135 \mathrm{~kg} \cdot \mathrm{ha}^{-1}$ & 122 & 121 & -1 & -.8 \\
\hline & $180 \mathrm{~kg} \cdot \mathrm{ha}^{-1}$ & 123 & 121 & -2 & -1.6 \\
\hline \multirow{5}{*}{ S-78 } & $0 \mathrm{~kg} \cdot \mathrm{ha}^{-1}$ & 100 & 105 & 5 & 5 \\
\hline & $45 \mathrm{~kg} \cdot \mathrm{ha}^{-1}$ & 100 & 105 & 5 & 5 \\
\hline & $90 \mathrm{~kg} \cdot \mathrm{ha}^{-1}$ & 101 & 105 & 4 & 3.9 \\
\hline & $135 \mathrm{~kg} \cdot \mathrm{ha}^{-1}$ & 103 & 105 & 2 & 1.9 \\
\hline & $180 \mathrm{~kg} \cdot \mathrm{ha}^{-1}$ & 105 & 105 & 0 & 0 \\
\hline Mean & & 2 & 1.9 & & \\
\hline RMSE & & 1.69 & & & \\
\hline
\end{tabular}

${ }^{\text {ap}} \mathrm{P}-\mathrm{O}=$ Predicted-Observed; RMSE $=$ Root Mean Square Error. 
Table 6. Comparison of observed and simulated values number of achene $\mathrm{m}^{-2}$ at different hybrids and different nitrogen rates.

\begin{tabular}{cccccc}
\hline Hybrids & Nitrogen Level $\left(\mathrm{kg} \cdot \mathrm{ha}^{-1}\right)$ & Observed & Predicted & ${ }^{\text {aP-O }}$ & PD (\%) \\
\hline & $0 \mathrm{~kg} \cdot \mathrm{ha}^{-1}$ & 5877 & 4489 & -1388 & 23.6 \\
& $45 \mathrm{~kg} \cdot \mathrm{ha}^{-1}$ & 5887 & 6977 & 1090 & 18.5 \\
Hysun-33 & $90 \mathrm{~kg} \cdot \mathrm{ha}^{-1}$ & 6073 & 8556 & 2483 & 40.9 \\
& $135 \mathrm{~kg} \cdot \mathrm{ha}^{-1}$ & 7622 & 9298 & 2576 & 38.3 \\
& $180 \mathrm{~kg} \cdot \mathrm{ha}^{-1}$ & 7543 & 9890 & 2347 & 31.1 \\
& $0 \mathrm{~kg} \cdot \mathrm{ha}^{-1}$ & 4867 & 4555 & -312 & -6.4 \\
& $45 \mathrm{~kg} \cdot \mathrm{ha}^{-1}$ & 6535 & 6841 & 306 & 4.8 \\
S-78 & $90 \mathrm{~kg} \cdot \mathrm{ha}^{-1}$ & 7291 & 7944 & 658 & 9.0 \\
& $135 \mathrm{~kg} \cdot \mathrm{ha}^{-1}$ & 8983 & 8464 & -512 & -5.8 \\
& $180 \mathrm{~kg} \cdot \mathrm{ha}^{-1}$ & 9244 & 8768 & -476 & -5.4 \\
& & & & 676.5 & 14.9 \\
Rean & & 1.60 & & & \\
\hline
\end{tabular}

${ }^{\mathrm{a}} \mathrm{P}-\mathrm{O}=$ Predicted-Observed RMSE $=$ Root Mean Square Error.

Table 7. Comparison of observed and simulated values of achene yield at different hybrids and different nitrogen rates.

\begin{tabular}{cccccc}
\hline Hybrids & Nitrogen Level $\left(\mathrm{kg}^{2} \cdot \mathrm{ha}^{-1}\right)$ & Observed & Predicted & ${ }^{\text {aP-O }}$ & PD (\%) \\
\hline & $0 \mathrm{~kg} \cdot \mathrm{ha}^{-1}$ & 2923 & 486 & -2437 & -83.4 \\
& $45 \mathrm{~kg} \cdot \mathrm{ha}^{-1}$ & 3078 & 1658 & -1420 & -46.1 \\
Hysun-33 & $90 \mathrm{~kg} \cdot \mathrm{ha}^{-1}$ & 3500 & 3315 & -185 & -5.2 \\
& $135 \mathrm{~kg} \cdot \mathrm{ha}^{-1}$ & 3884 & 3944 & 60 & 1.5 \\
& $180 \mathrm{~kg} \cdot \mathrm{ha}^{-1}$ & 3935 & 3915 & -20 & -0.5 \\
& $0 \mathrm{~kg} \cdot \mathrm{ha}^{-1}$ & 3212 & 496 & -2716 & -84.6 \\
& $45 \mathrm{~kg} \cdot \mathrm{ha}^{-1}$ & 3406 & 2028 & -1378 & -40.4 \\
S-78 & $90 \mathrm{~kg} \cdot \mathrm{ha}^{-1}$ & 3805 & 3314 & -491 & -12.9 \\
& $135 \mathrm{~kg} \cdot \mathrm{ha}^{-1}$ & 4055 & 3671 & -384 & -9.5 \\
& $180 \mathrm{~kg} \cdot \mathrm{ha}^{-1}$ & 4095 & 2932 & -1163 & -28.4 \\
& & & & -1013 & -30.9 \\
Mean & & 191.81 & & & \\
\hline
\end{tabular}

${ }^{\text {a }} \mathrm{P}-\mathrm{O}=$ Predicted-Observed RMSE $=$ Root Mean Square Error.

lated (3935 $\left.\mathrm{kg} \cdot \mathrm{ha}^{-1}\right)$ and observed $\left(3915 \mathrm{~kg} \cdot \mathrm{ha}^{-1}\right)$, value for achene yield was in hybrid Hyun-33 with nitrogen application $180 \mathrm{~kg} \cdot \mathrm{ha}^{-1}$. In generally, all values are almost close to each other. However, maximum difference was in Hysun-33 without receiving of Nitrogen. The OILCROP-SUN model was also calibrate for hybrid S-78 and results showed the smallest difference between simulated (3671 $\mathrm{kg} \cdot \mathrm{ha}^{-1}$ ) and observed (4055 kg.ha-1), value for achene yield with nitrogen application $135 \mathrm{~kg} \cdot \mathrm{ha}^{-1}$. In general, all values are almost close to each other. However, 
maximum difference was in S-78 hybrid in control treatment, where model over estimated similar approaches were explained by [17] [19].

\subsection{Total Dry Matter (kg·ha-1)}

The OILCROP-SUN model simulated final total dry matter well and calibrated results described there was a small difference in total dry matter (TDM) between observed $\left(11,586 \mathrm{~kg} \cdot \mathrm{ha}^{-1}\right)$ and simulate $\left(10,970 \mathrm{~kg} \cdot \mathrm{ha}^{-1}\right)$ values for Sunflower 33and also minimum difference was noted between observed $\left(9496 \mathrm{~kg} \cdot \mathrm{ha}^{-1}\right)$ and simulated $\left(8623 \mathrm{~kg} \cdot \mathrm{ha}^{-1}\right)$ values of hybrid S-78. The OILCROP-SUN model also simulated total dry matter well and the calibration results described that maximum value for root mean error (RMSE) was observed 735 are shown in Table 8. All results of TDM was generated from DSSAT as shown in Figures 1-10.

\subsection{Leaf Area Index}

The OILCROP-SUN model was able to simulate leaf area index well and calibration results described there was a small difference between observed and simulate value (0.19) of leaf area index in Hysun-33 with treatment level of (135 $\mathrm{kg} \mathrm{N} \mathrm{ha}{ }^{-1}$ ). However, highest (1.6) difference was in control treatment where model over estimated. In general, model over estimated the value of LAI. The OILCROP-SUN model was able to simulated leaf area index well and calibration results described there was a small difference between observed and simulated value (1.26) of leaf area index in S-78 with application level of $\left(135 \mathrm{~kg} \mathrm{~N} \mathrm{ha}^{-1}\right)$. However, highest (2.18) difference was in control treatment where model over estimated. In general, model over estimated the value of LAI as shown in Figure 11 and Figure 12.

Table 8. Comparison of observed and simulated values of total dry matter at different sunflower hybrids and different nitrogen rates.

\begin{tabular}{|c|c|c|c|c|c|}
\hline Hybrids & Nitrogen Level $\left(\mathrm{kg} \cdot \mathrm{ha}^{-1}\right)$ & Observed & Predicted & ${ }^{\mathrm{a}} \mathrm{P}-\mathrm{O}$ & PD (\%) \\
\hline \multirow{5}{*}{ Hysun-33 } & $0 \mathrm{~kg} \cdot \mathrm{ha}^{-1}$ & 7771 & 1212 & -6559 & -84.4 \\
\hline & $45 \mathrm{~kg} \cdot \mathrm{ha}^{-1}$ & 8529 & 5097 & -3432 & -40.2 \\
\hline & $90 \mathrm{~kg} \cdot \mathrm{ha}^{-1}$ & 9725 & 8155 & -1570 & -16.1 \\
\hline & $135 \mathrm{~kg} \cdot \mathrm{ha}^{-1}$ & 11,123 & 9734 & -1389 & -124.8 \\
\hline & $180 \mathrm{~kg} \cdot \mathrm{ha}^{-1}$ & 11,586 & 10970 & -616 & -53.1 \\
\hline \multirow{5}{*}{$\mathrm{S}-78$} & $0 \mathrm{~kg} \cdot \mathrm{ha}^{-1}$ & 7518 & 1128 & -6390 & -85 \\
\hline & $45 \mathrm{~kg} \cdot \mathrm{ha}^{-1}$ & 7676 & 5004 & -2672 & -34.9 \\
\hline & $90 \mathrm{~kg} \cdot \mathrm{ha}^{-1}$ & 8555 & 7492 & -1063 & -12.4 \\
\hline & $135 \mathrm{~kg} \cdot \mathrm{ha}^{-1}$ & 9496 & 8623 & -873 & -9.0 \\
\hline & $180 \mathrm{~kg} \cdot \mathrm{ha}^{-1}$ & 9722 & 8450 & -1272 & -13.0 \\
\hline Mean & & -2583.6 & -47.29 & & \\
\hline RMSE & \multicolumn{5}{|c|}{735} \\
\hline
\end{tabular}

${ }^{\mathrm{a}} \mathrm{P}-\mathrm{O}=$ Predicted-Observed, RMSE $=$ Root Mean Square Error. 


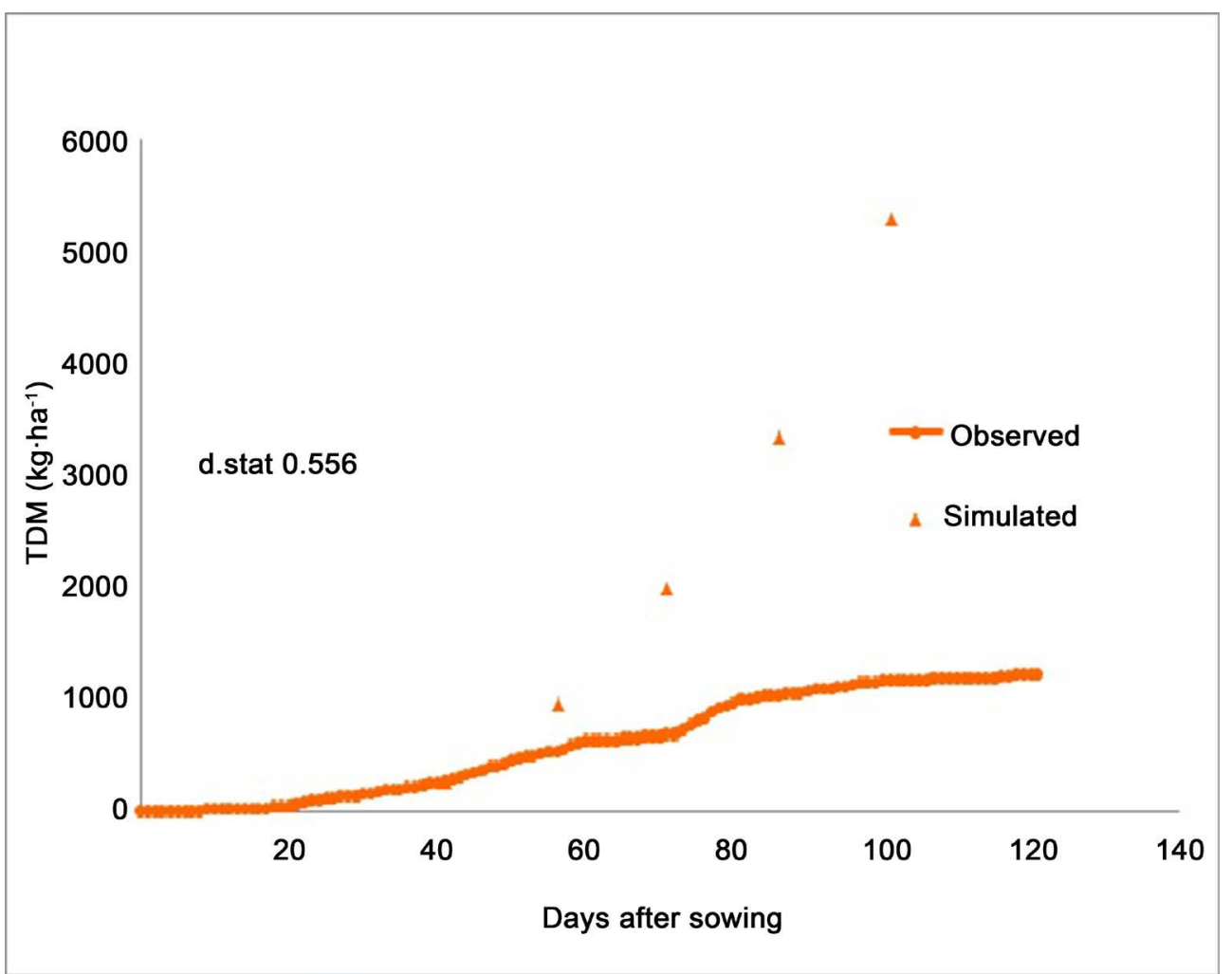

Figure 1. Comparison of observed and simulated values of TDM for treatment $\mathrm{H}_{1} \mathrm{~N}_{1}\left(\mathrm{H}_{1}=\mathrm{Hy}-\right.$ sun-33 and $\mathrm{N}_{1}=0 \mathrm{~kg} \mathrm{~N} \mathrm{ha}^{-1}$ ).

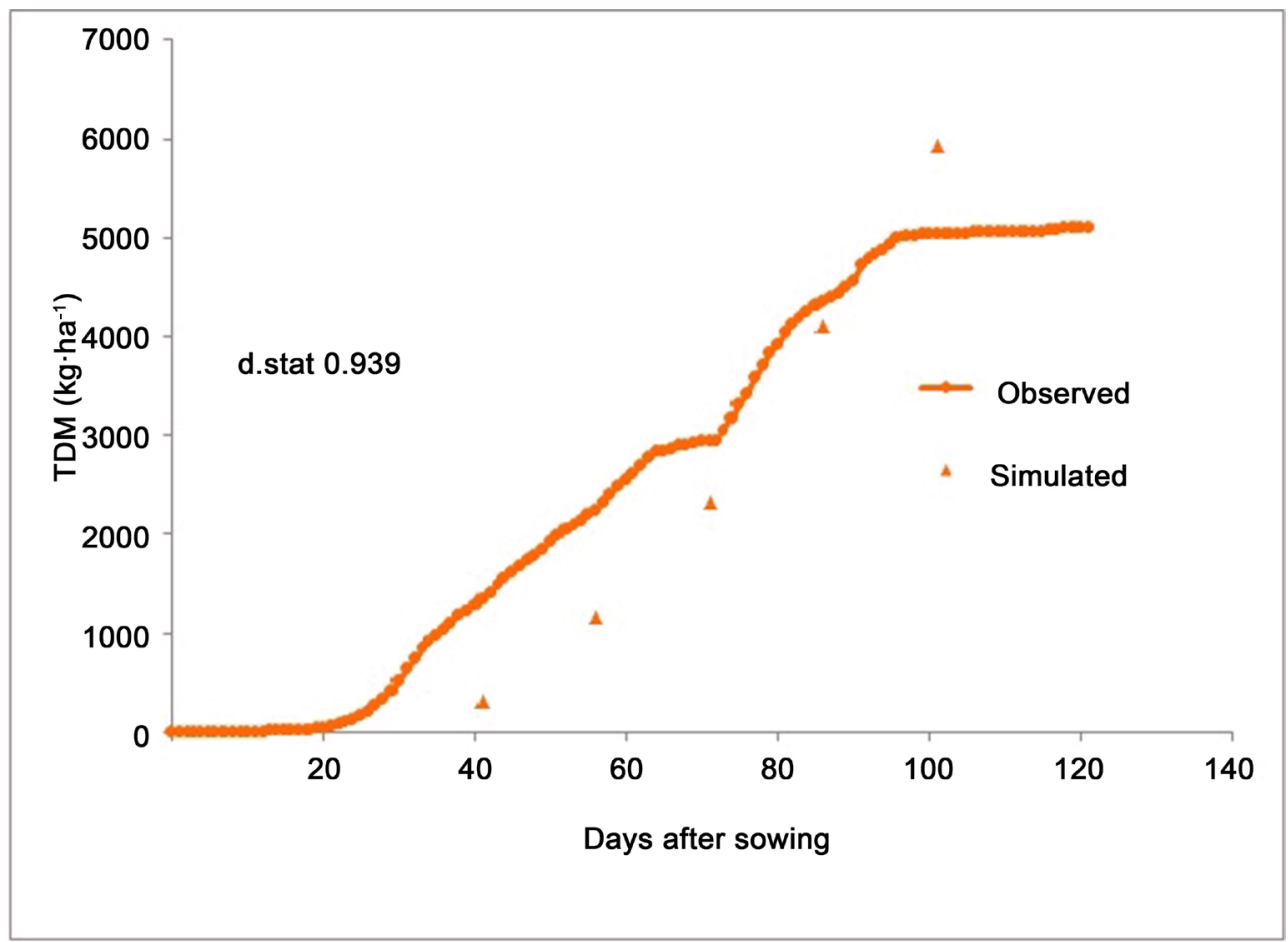

Figure 2. Comparison of observed and simulated values of TDM for treatment $\mathrm{H}_{1} \mathrm{~N}_{2}\left(\mathrm{H}_{1}=\mathrm{Hy}\right.$ sun-33 and $\mathrm{N}_{2}=45 \mathrm{~kg} \mathrm{~N} \mathrm{ha}^{-1}$ ). 


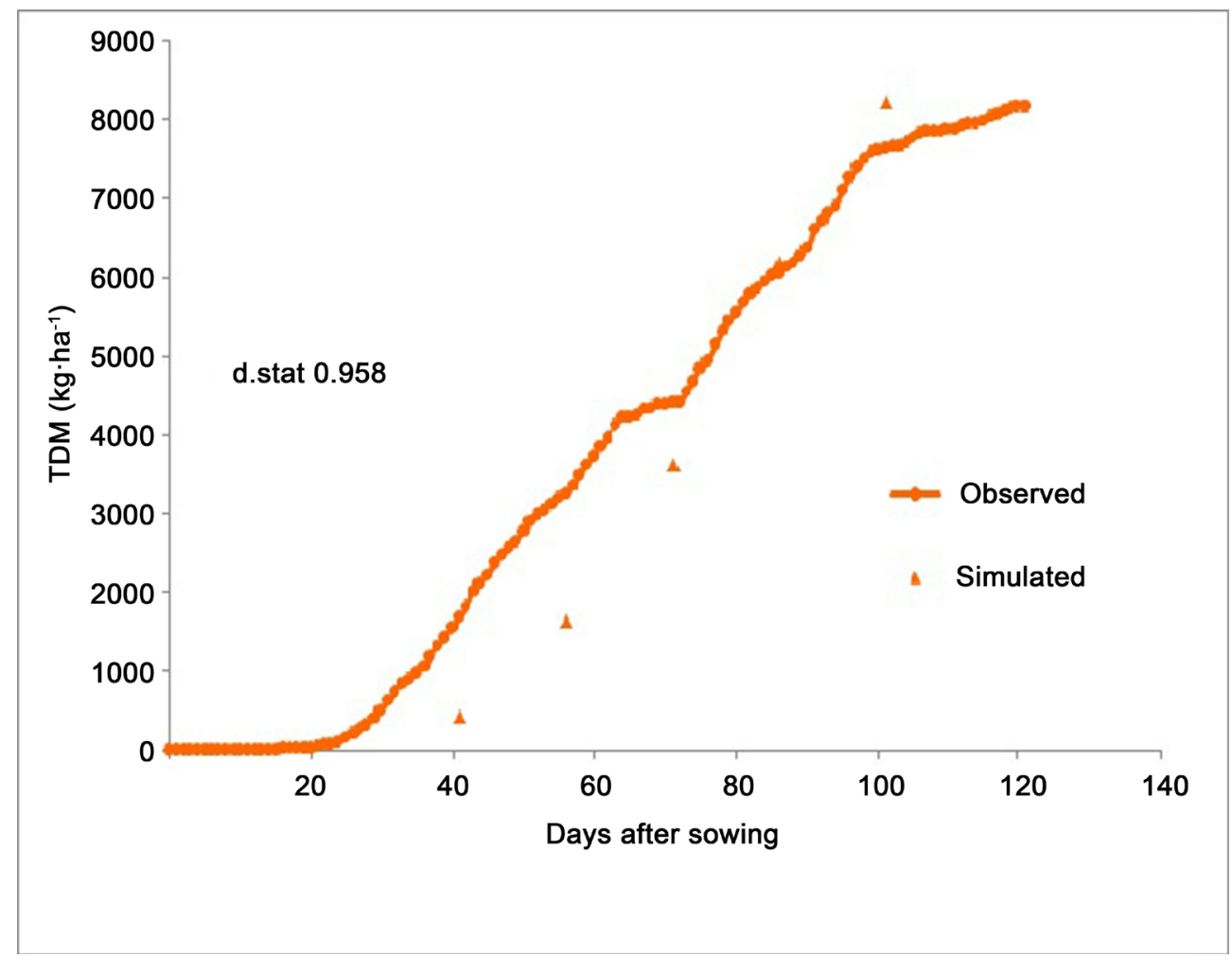

Figure 3. Comparison of observed and simulated values of TDM for treatment $\mathrm{H}_{1} \mathrm{~N}_{3}\left(\mathrm{H}_{1}=\mathrm{Hy}\right.$ sun-33 and $\mathrm{N}_{3}=90 \mathrm{~kg} \mathrm{~N} \mathrm{ha}{ }^{-1}$ ).

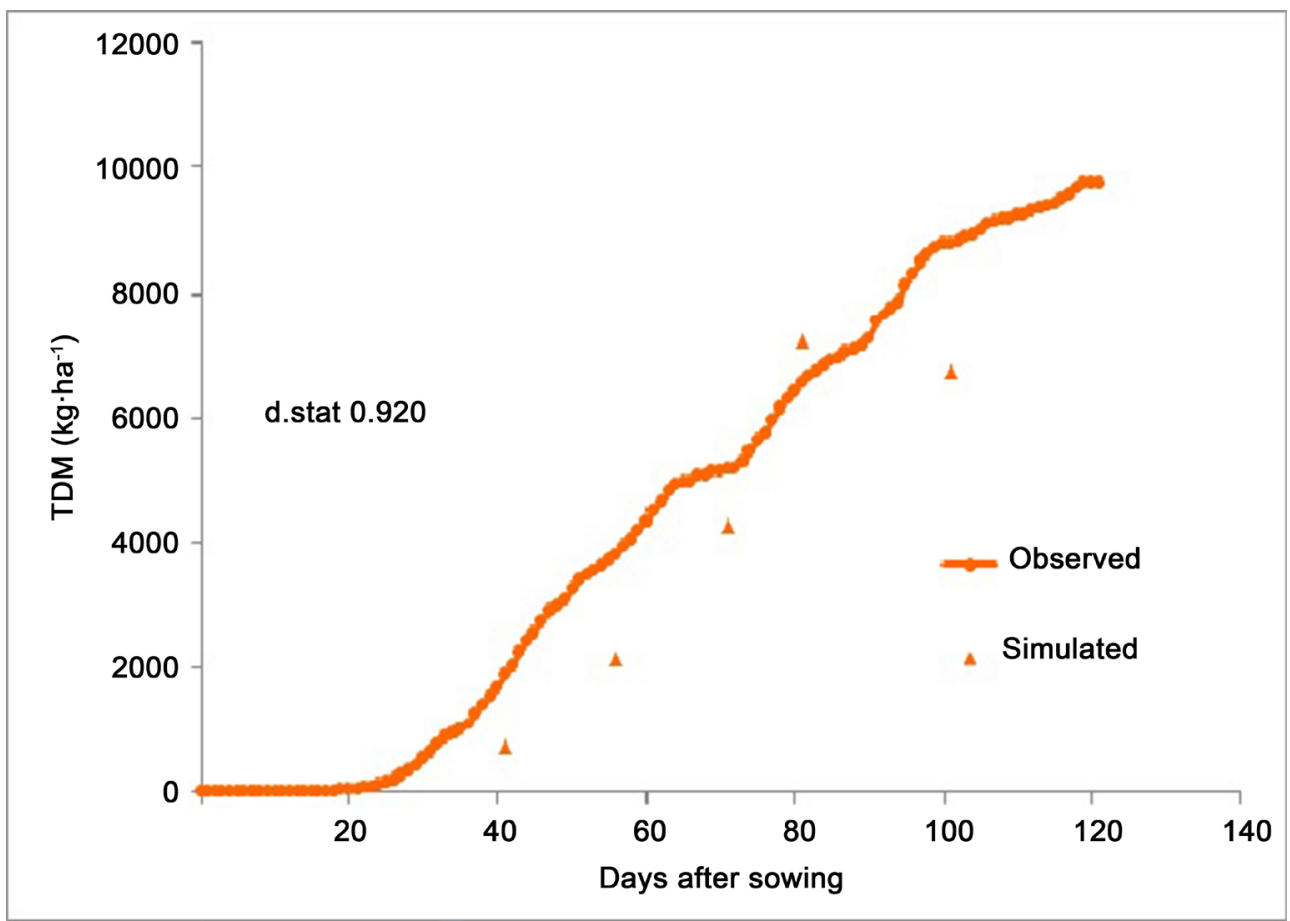

Figure 4. Comparison of observed and simulated values of TDM for treatment $\mathrm{H}_{1} \mathrm{~N}_{4}\left(\mathrm{H}_{1}=\mathrm{Hy}\right.$ sun-33 and $\mathrm{N}_{4}=135 \mathrm{~kg} \mathrm{~N} \mathrm{ha}^{-1}$ ). 


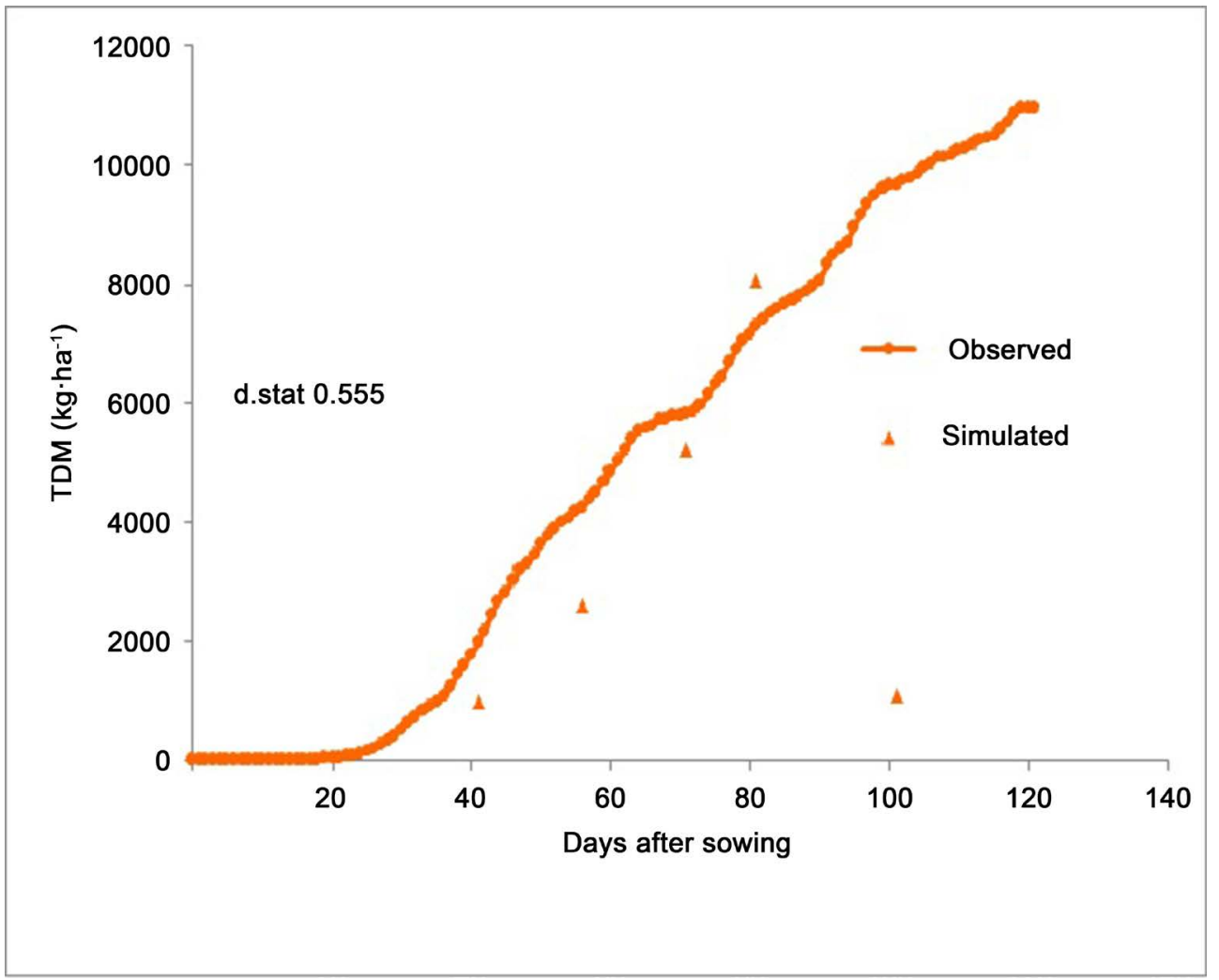

Figure 5. Comparison of observed and simulated values of TDM for treatment $\mathrm{H}_{1} \mathrm{~N}_{5}\left(\mathrm{H}_{1}=\mathrm{Hy}\right.$ sun-33 and $\mathrm{N}_{5}=180 \mathrm{~kg} \mathrm{~N} \mathrm{ha}^{-1}$ ).

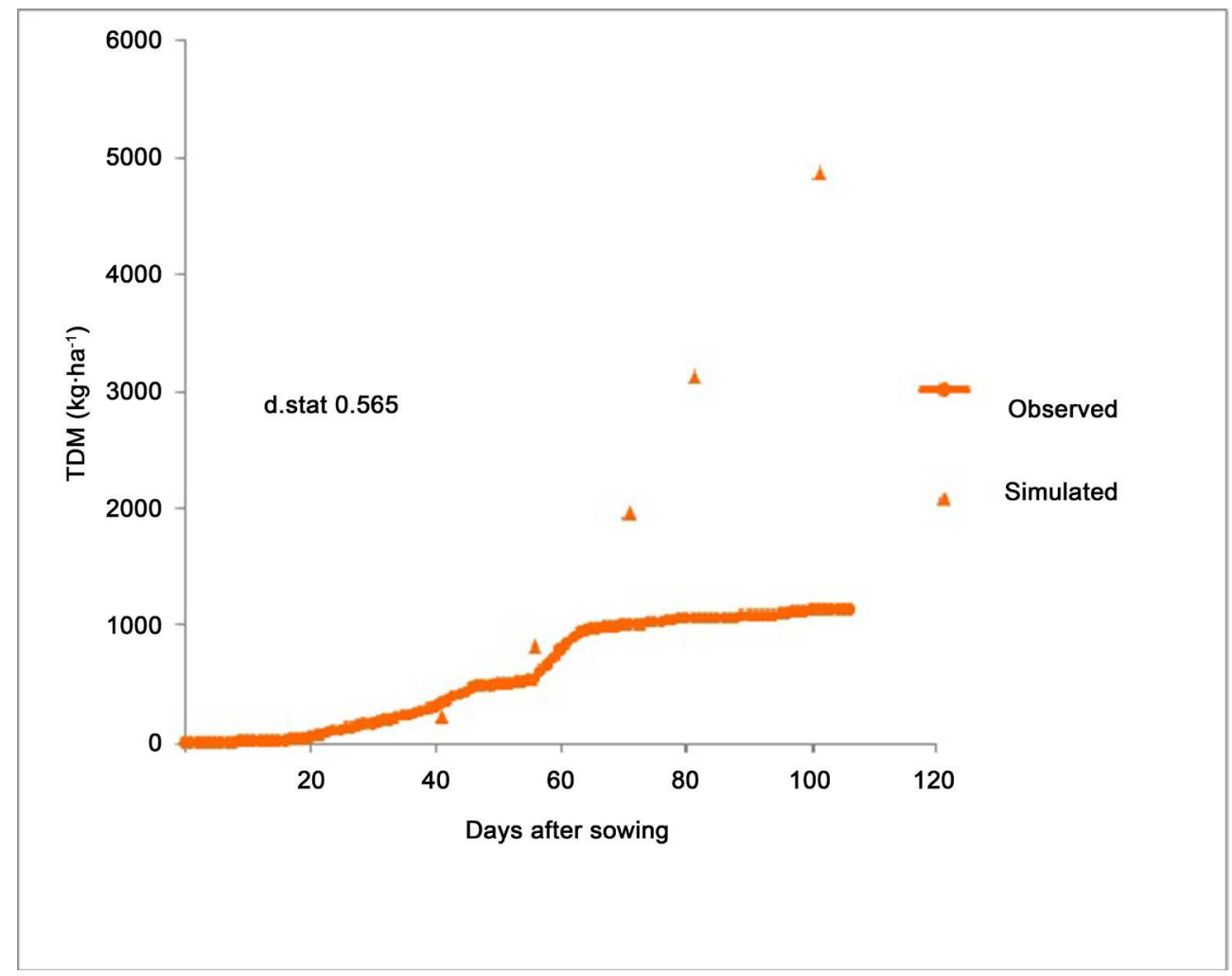

Figure 6. Comparison of observed and simulated values of TDM for treatment $\mathrm{H}_{2} \mathrm{~N}_{1}\left(\mathrm{H}_{1}=\mathrm{Hy}\right.$ sun-33 and $\mathrm{N}_{1}=0 \mathrm{~kg} \mathrm{~N} \mathrm{ha}{ }^{-1}$ ). 


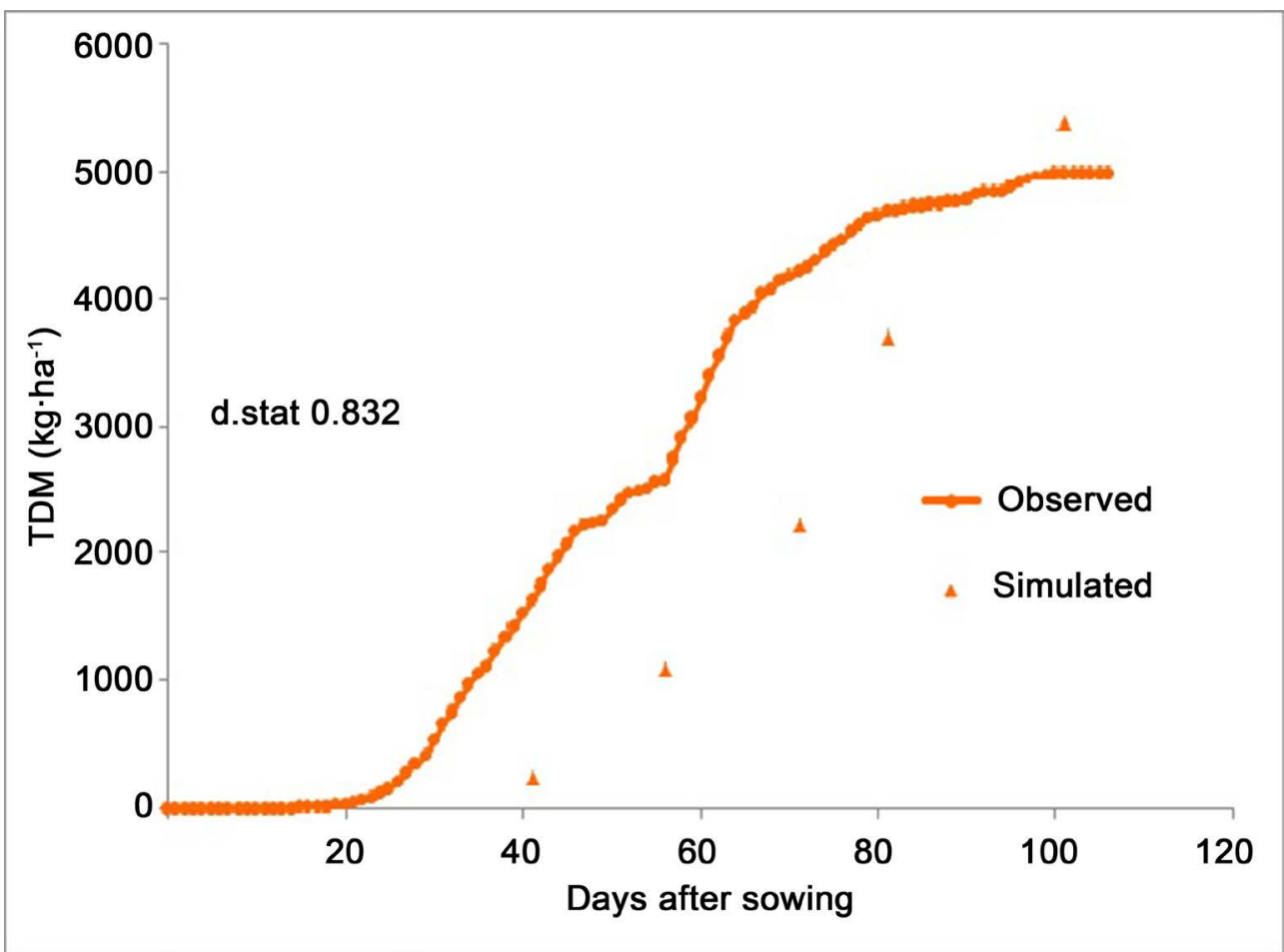

Figure 7. Comparison of observed and simulated values of TDM for treatment $\mathrm{H}_{2} \mathrm{~N}_{2}\left(\mathrm{H}_{1}=\mathrm{Hy}-\right.$ sun-33 and $\mathrm{N}_{2}=45 \mathrm{~kg} \mathrm{~N} \mathrm{ha}^{-1}$ ).

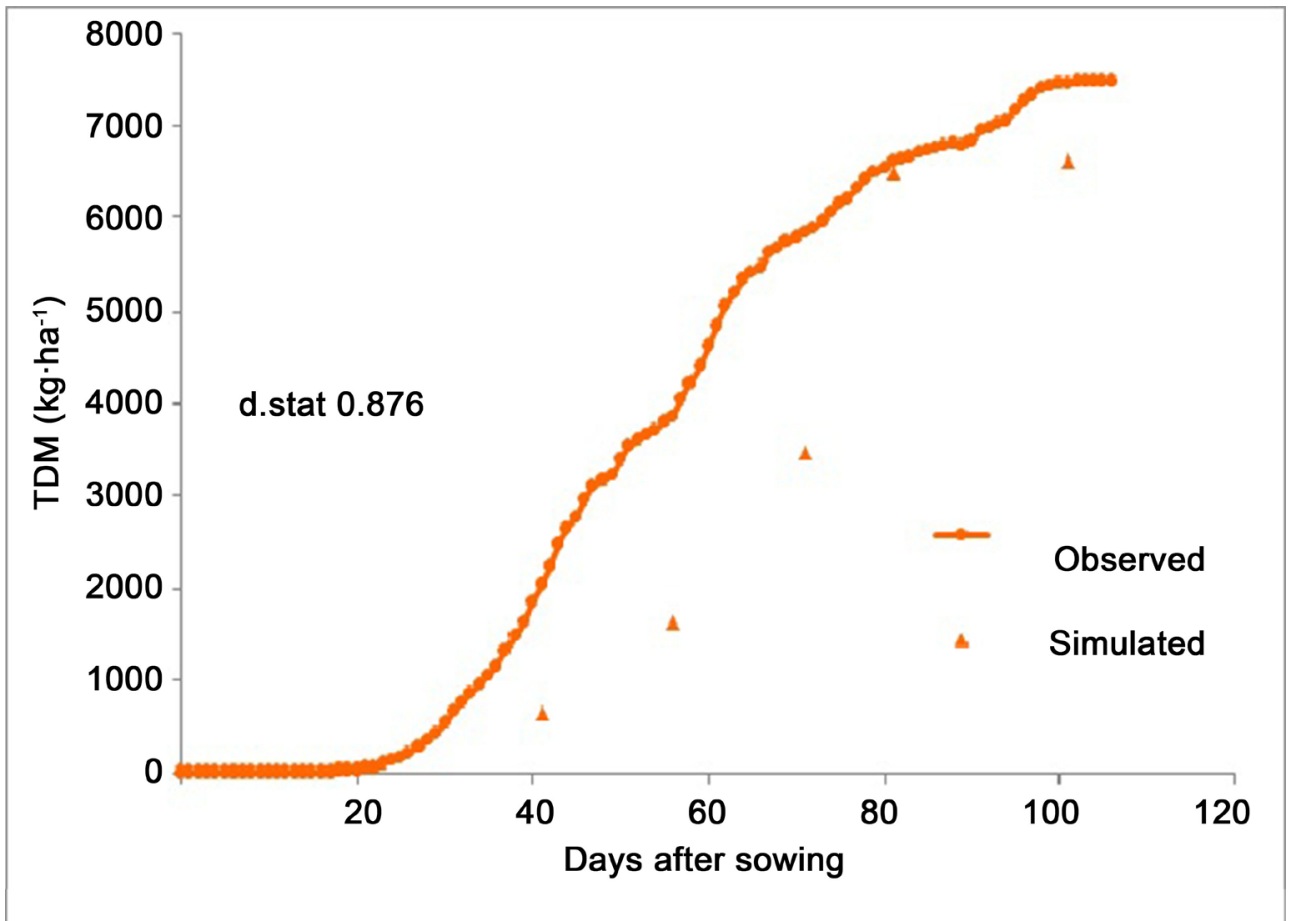

Figure 8. Comparison of observed and simulated values of TDM for treatment $\mathrm{H}_{2} \mathrm{~N}_{3}\left(\mathrm{H}_{1}=\mathrm{Hy}\right.$ sun-33 and $\mathrm{N}_{3}=90 \mathrm{~kg} \mathrm{~N} \mathrm{ha}{ }^{-1}$ ). 


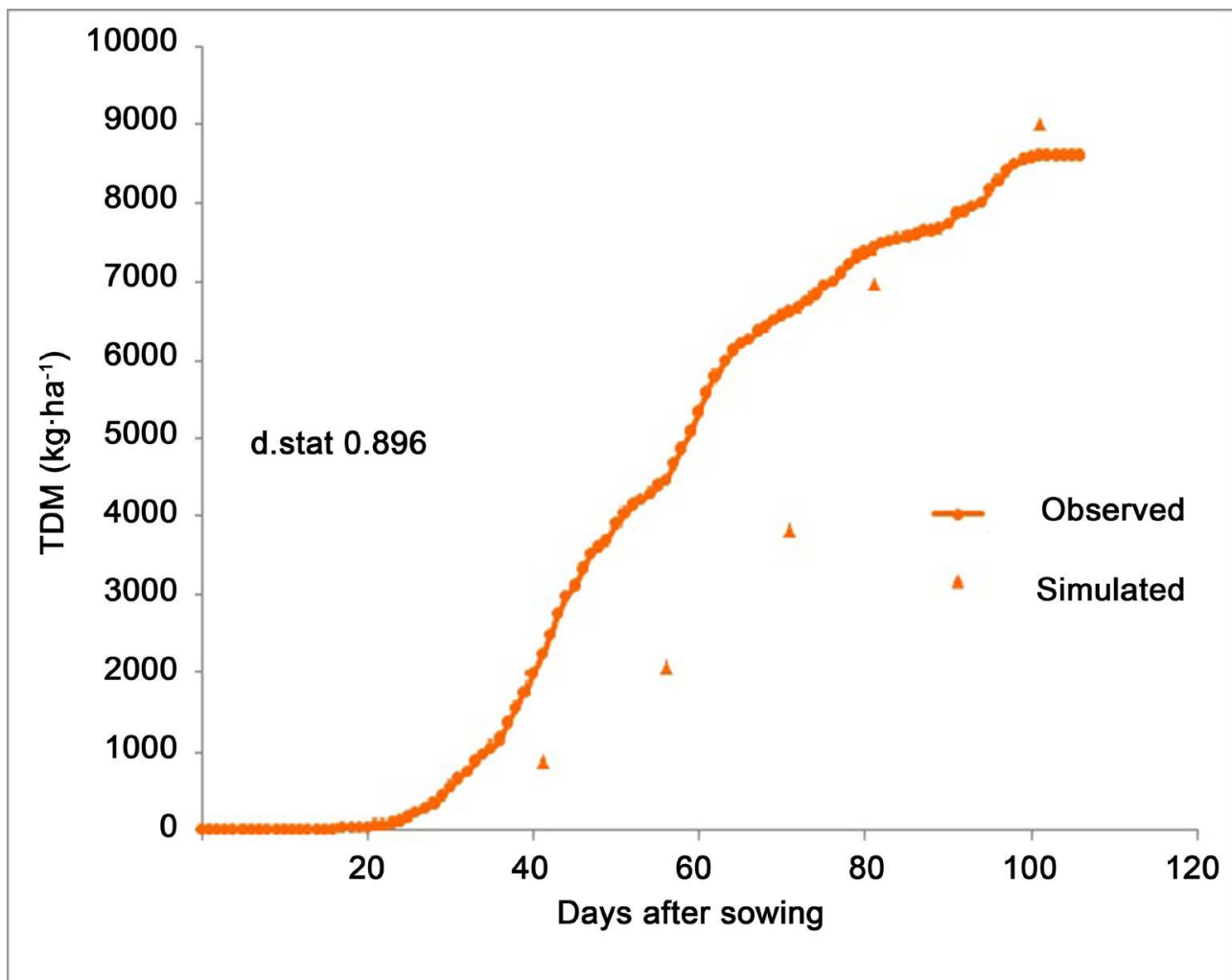

Figure 9. Comparison of observed and simulated values of TDM for treatment $\mathrm{H}_{2} \mathrm{~N}_{4}\left(\mathrm{H}_{1}=\mathrm{Hy}\right.$ sun-33 and $\mathrm{N}_{4}=135 \mathrm{~kg} \mathrm{~N} \mathrm{ha}^{-1}$ ).

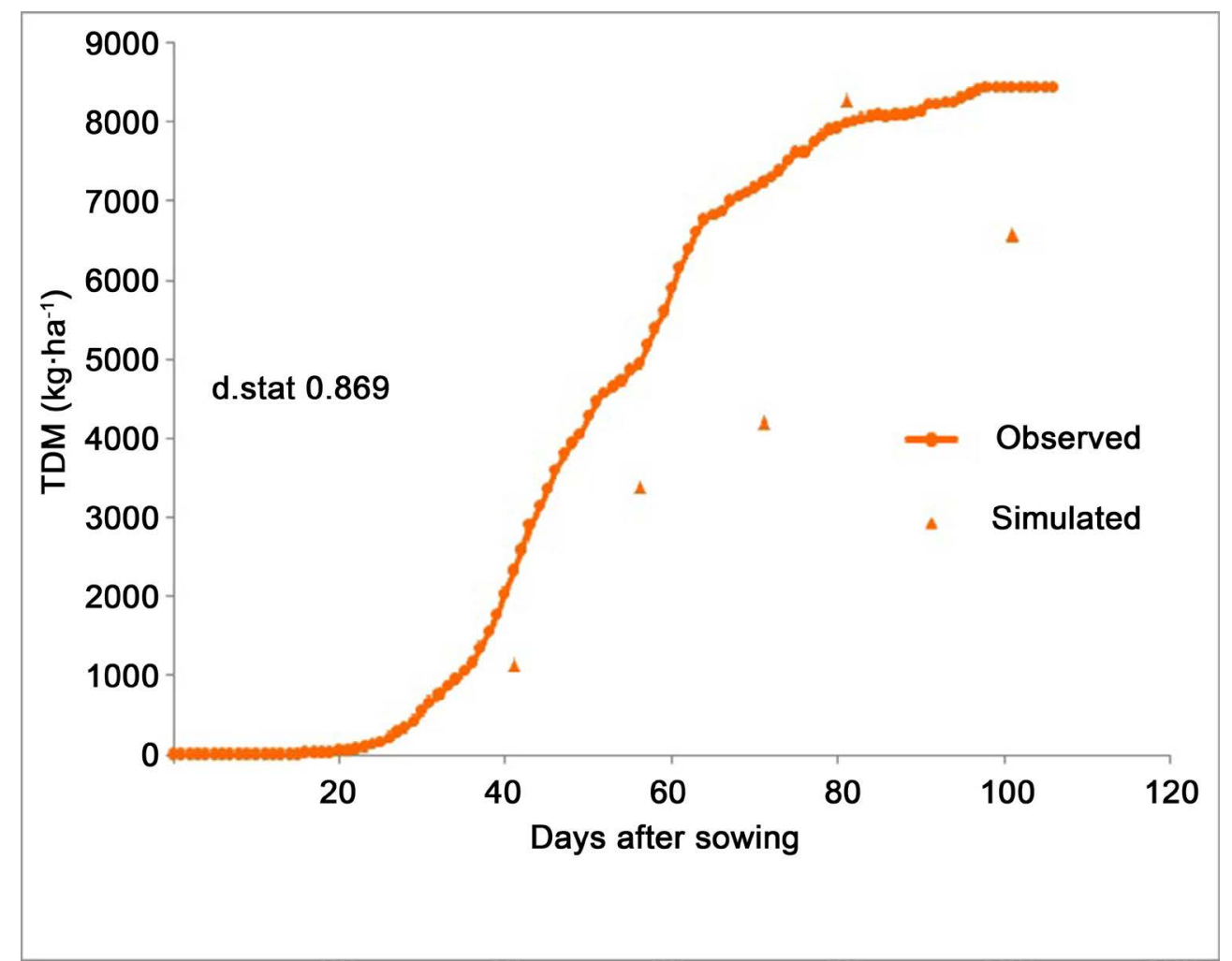

Figure 10. Comparison of observed and simulated values of TDM for treatment $\mathrm{H}_{2} \mathrm{~N}_{5}\left(\mathrm{H}_{1}=\mathrm{Hy}\right.$ sun-33 and $\mathrm{N}_{5}=180 \mathrm{~kg} \mathrm{~N} \mathrm{ha}^{-1}$ ). 


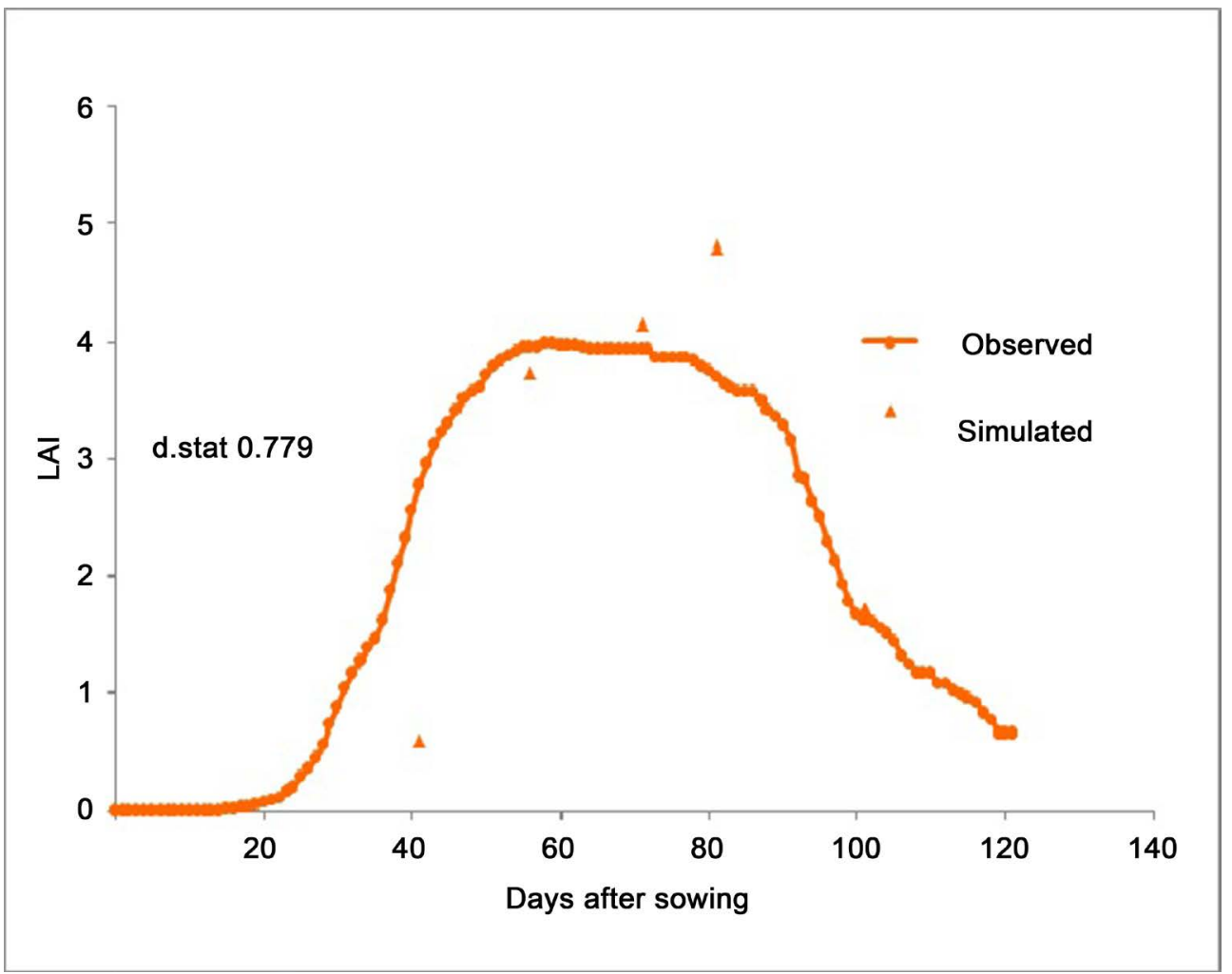

Figure 11. Comparison of observed and simulated values of LAI for treatment $\mathrm{H}_{1} \mathrm{~N}_{4}\left(\mathrm{H}_{1}=\mathrm{Hy}\right.$ sun-33 and $\mathrm{N}_{4}=135 \mathrm{~kg} \mathrm{~N} \mathrm{ha}^{-1}$ ).

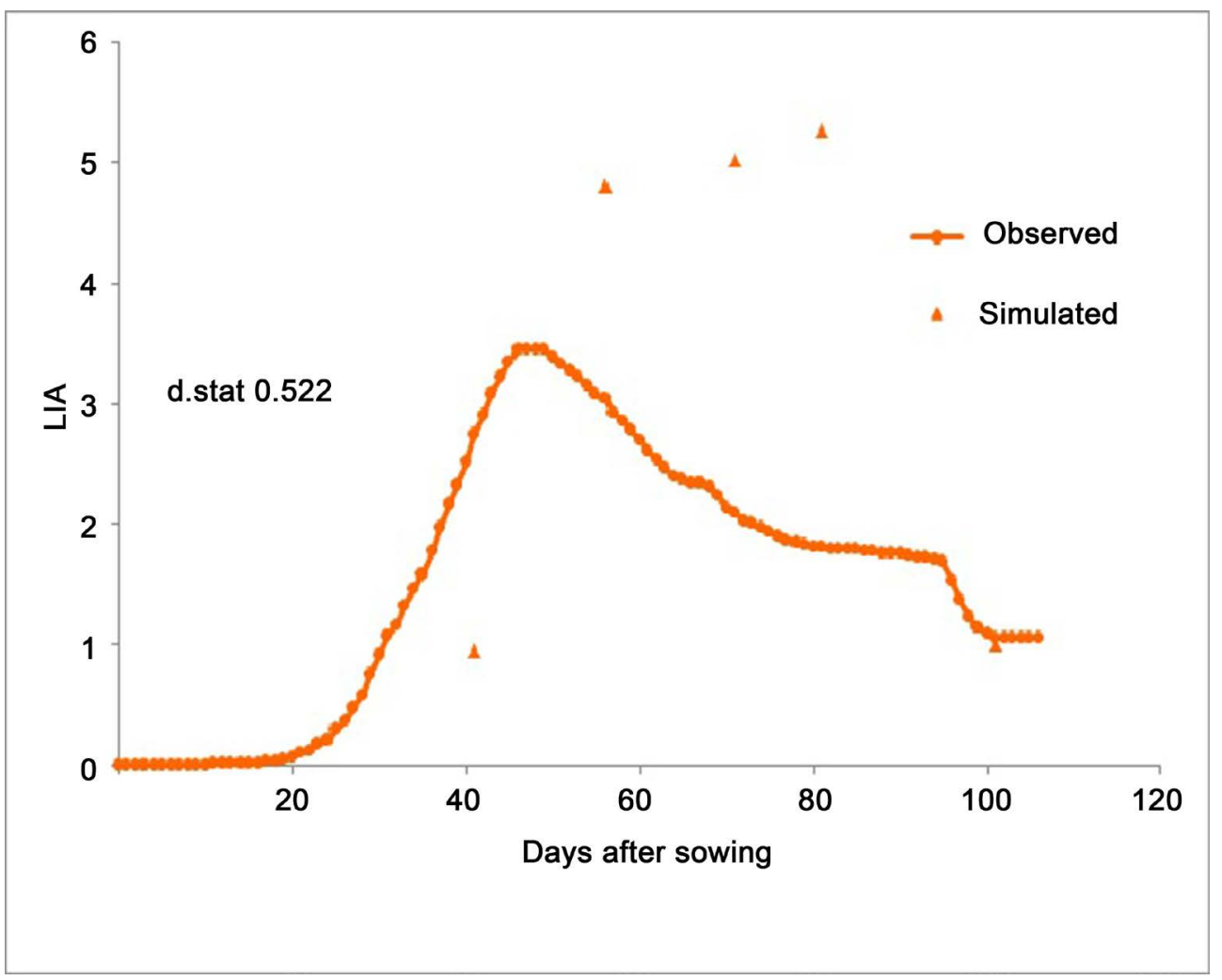

Figure 12. Comparison of observed and simulated values of TDM for treatment $\mathrm{H}_{2} \mathrm{~N}_{4}\left(\mathrm{H}_{1}=\mathrm{Hy}\right.$ sun-33 and $\mathrm{N}_{4}=135 \mathrm{~kg} \mathrm{~N} \mathrm{ha}^{-1}$ ). 


\section{Conclusion}

Crop modeling is becoming a valuable tool to understand and mimic climatic constraints and yield gaps. The outcomes of the study clearly depicted that DSSAT model is predicted crop growth and yield parameters of sunflower crop. This study also showed the OIL-CROP-SUN model served as a tool for determining the best nitrogen levels for growing sunflower under irrigated conditions in semi-arid environment in Pakistan. This study illustrates the potential for using crop simulations models as information technology for determining suitable management strategies for sunflower production in Sargodha, Punjab, Pakistan. Therefore, we can conclude that the OILCROP-SUN model could potentially assist resource-poor farmers in Pakistan and provide them with alternate management options.

\section{References}

[1] GoP. Agricultural Statistics of Pakistan, Govt. of Pakistan, Ministry of Food, Agriculture and Livestock, Economic Wing. Islamabad, Pakistan. 2009-10.

[2] Unger, P.W. (1990) Sunflower. In: Stewart and Nielson, D.R., Eds., Irrigation of Agriculture Crops, ASA Monograph No. 30, ASA.CSSA, SSSA, Madison, 775-791.

[3] Bakht, J., Ahmad, S., Tariq, M., Akber, H. and Shafi, M. (2006) Performance of Various Hybrids of Sunflower in Peshawar Valley. Journal of Agriculture and Biological Science.

[4] Jahangir, A.A., Mondal, R.K., Nada, K., Afroze, R.S. and Hakim, M.A. (2006) Respose of Nitrogen and Phosphorus Fertilizer and Plant Spacing on Growth and Yield Contributing Character of Sunflower. Bangladesh Journal of Scientific and Industrial Research, 41, 33-40.

[5] Suzer, S. (2010) Effect of Nitrogen and Plant Density on Dwarf Sunflower Hybrids. Helia, 33, 207-214.

[6] Hussein, M.A., El-Hattab, A.H. and Ahmed, A.K. (1980) Effect of Plant Spacing and Nitrogen Levels on Morphological Characters, Seed Yield and Quality in Sunflower (Helianthus annuus L.). Journal of Agronomy and Crop Science, 149, 148-156.

[7] Blamey, F.P.C. and Chapman, J. (1981) Protein, Oil, and Energy Yields of Sunflower as Affected by N and P Fertilization. Agronomy Journal, 73, 583-587. https://doi.org/10.2134/agronj1981.00021962007300040004x

[8] Kandil, A.A. (1984) Response of Some Sunflower Cultivars to Different Fertility Levels. Journal of Agronomy and Crop Science, 153, 401-406.

[9] Narwal, S.S. and Malik, D.S. (1995) Response of Sunflower Cultivars to Plant Density and Nitrogen. J. Agric. Sci. Camb., 104, 95-97.

[10] Khokani, M.G., Ahlawat, R.P.S. and Trivedi, S.J. (1993) Effect of Nitrogen and Phosphorus on Growth and Yield of Sunflower (Helianthus annuus). Indian Journal of Agronomy, 38, 507-509.

[11] Legha, P.K. and Giri, G. (1999) Influence of Nitrogen and Sulphur on Growth, Yield and Oil Content of Sunflower (Helianthus annuus) Grown in Spring Season. Indian Journal of Agronomy, 44, 408-412.

[12] Tomar, H.P.S., Dadhwal, K.S. and Sing, H.P. (1999) Effect of Irrigation, N, and P on Yield and Yield Attributes of Spring Sunflower (Helianthus annuus L.). Trop. Agric., 76, 228-231.

[13] Zubillaga, M.M., Aristi, J.P. and Lavado, R.S. (2002) Effect of Phosphorus and Ni- 
trogen Fertilization on Sunflower (Helianthus annuus L.) Nitrogen Uptake and Yield. Journal of Agronomy and Crop Science, 188, 267-274. https://doi.org/10.1046/j.1439-037X.2002.00570.x

[14] Malik, M.A., Saleem, M.F., Sana, M. and Rehman, A. (2004) Suitable Levels of N, P and $\mathrm{K}$ for Harvesting the Maximum Returns of Sunflower. International Journal of Agriculture and Biology, 6, 240-242.

[15] Penning, D.V. (1977) Evaluation of Simulation Models in Agriculture and Biology: Conculsion of Workshop. Agriculture Systems, 2, 99-107. https://doi.org/10.1016/0308-521X(77)90063-4

[16] IBSRAM (1994) Soil Water and Nutrient Management Research. A New Agenda (CGIAR Document MT/94/07). International Board for Soil Research and Management, Thailand.

[17] Fourcaud, T., Stokes, A., Lambers, H. and Korner, C. (2008) Plants Growth Modeling and Application: The Increasing Importance of Plant Architecture in Growth Models. Annals of Botany, 101, 1053-1063. https://doi.org/10.1093/aob/mcn050

[18] Gholipouri, A., Sharifi, R.S., Sedghi, M. and Heydri, A. (2009) Modeling Growth AND Yield of Sunflowe (Helianthus annus L.). Recent Research in Science and Technology, 1, 239-242.

[19] Hoogenboom, G., Jones, J.W., Wilkens, P.W., Porter, C.H., Batchelor, W.D., Hunt, L.A., Boote, K.J., Singh, U., Uryasev, O., Boown, W.T., Gijsman, A., du Toit, A., White, J.W. and Tsuji, G.Y. (2004) Decision Support System for Agrotechnology Transfer. Version 4.0, University of Hawaii, Honolulu.

[20] Pereyra-Irujo, G.A. and Aguirrezabal, L.A.N. (2007) Sunflower Yield and Oil Quality Interactions and Variability: Analysis through a Simple Simulation Model. Agricultural and Forest Meteorology, 143, 252-265. https://doi.org/10.1016/j.agrformet.2007.01.001

[21] Tyagi, N.K., Sharma, D.K. and Luthra, S.K. (2008) Determination of Evapo-Transpiration and Crop Coefficients of Rice and Sunflower with Lysimeter. Agricultural Water Management, 45, 41-54. https://doi.org/10.1016/S0378-3774(99)00071-2

[22] Diodato, N. and Bellocchi, G. (2007) Modelling Solar Radiation over Complex Terrains Using Monthly Climatological Data. Agricultural and Forest Meteorology, 144, 111-126. https://doi.org/10.1016/j.agrformet.2007.02.001

[23] Villalobos, F.J., Hall, A.J., Ritchie, J.T. and Orgaz, F. (1996) OILCROP-SUN: A Development, Growth, and Yield Model of Sunflower Crop. Agronomy Journal, 88, 403-415. https://doi.org/10.2134/agronj1996.00021962008800030008x

[24] Rinaldi, M., Losavio, N. and Flagella, Z. (2003) Evaluation and Application of OILCROP-SUN Model for Sunflower in Southern Italy. Agricultural Systems, 78, 17-30. https://doi.org/10.1016/S0308-521X(03)00030-1 
Submit or recommend next manuscript to SCIRP and we will provide best service for you:

Accepting pre-submission inquiries through Email, Facebook, LinkedIn, Twitter, etc. A wide selection of journals (inclusive of 9 subjects, more than 200 journals)

Providing 24-hour high-quality service

User-friendly online submission system

Fair and swift peer-review system

Efficient typesetting and proofreading procedure

Display of the result of downloads and visits, as well as the number of cited articles Maximum dissemination of your research work

Submit your manuscript at: http://papersubmission.scirp.org/

Or contact ajps@scirp.org 